\title{
SPATIAL AND TRANSPORT DEVELOPMENT ALONG EUROPEAN CORRIDORS: STRENGTHENING THE CAPACITY OF LOCAL STAKEHOLDERS IN TRANSNATIONAL COOPERATION
}

\section{A B S T R R A C T}

Integrated spatial and transport corridor development is one of the strategies to affect trade, economic and demographic performance in linear systems around the world. However, such development can be elaborated at different levels: from exploring the dynamics of transnational cooperation, across analysing the extent of integration between spatial and transport policies within the states along the corridor, to focusing on the role of local stakeholders in supranational issues. Since this paper presents the initial phase of the European project on transnational cooperation in the domain of integrated spatial and transport development along the Hamburg-Athens corridor, the paper aims at providing a scientific-based overview on the mentioned corridor in the frame of an infrastructure programme initiated by the European Commission. The character of the paper is mainly descriptive thus elucidating the on-going research being conducted through the mentioned project. For this purpose, the multi-scalar perspective (i.e. global, regional, local) is used to analyse several indicators regarding the trade, economy and demography. Such a thorough overview is believed to provide a better examination of the current situation. Some general recommendations for strengthening the role of local authorities in a complex process of transnational cooperation are briefly given in the final part of the paper. 


\section{INTRODUCTION}

The paper presents a brief overview on the initial phase of the on-going research project Spatial and Transport Development in European Corridors: Example Corridor 22, Hamburg-Athens. ${ }^{1}$ Because of the project group different research entities in order to better respond to the challenges and questions posed in the mentioned corridor defined previously by the European Commission (EC) within the TEN-T (Trans-European Transport Networks) programme, ${ }^{2}$ the aim of the project is to develop a comprehensive strategic programme for the future integrated spatial and transport development of the entire corridor. As a matter of elucidating the large-scale sustainable infrastructure policy, the project is particularly focused on the rail transport (both passenger and freight), brownfield regeneration as a mechanism to exploit urban development potential and advanced methods and the tools for a better institutional cooperation.

Three main assumptions influence the research done so far. Firstly, a thorough overview based on scientific data is understood as a necessary condition for a successful 'diagnostic' of the current situation along the corridor. Secondly, there is a need for a multiple scale analysis (i.e. analysis at global, regional and local level) as the globalisation process interconnects the mechanisms performed at different scales to each other. Thirdly, intensive research on the here presented topic may increase the interest from the society, in general, and competent authorities, in particular, to tackle the unsolved issues.

Although officially named as the Orient/east-Med(iterranean) corridor, in this paper we will use the term Corridor 22 in order to announce the corridor area stretching from Hamburg to Athens. ${ }^{3}$ Such a name is used for both the statistical purpose and to simplify the denomination for the group of countries as a territorial scope of this research project. Namely, the group comprises 11 countries: Austria, Bulgaria, Cyprus, the Czech Republic, Former Yugoslav Republic of Macedonia (FYROM), Germany, Greece, Hungary, Romania, Serbia, and Slovakia. The selection of the analysed countries is made based on the corridor definition by the EC. Both Serbia and FYROM are included in the analysis although excluded by the EC documents. It is believed that both states (especially Serbia) are the key actors both from a geostrategic position as well as a foreign investment attractor for the overall cohesion of the Corridor 22. Cyprus is also included in the statistical analysis as the official TEN-T programme considers its membership. However, the island state is left apart from the infrastructure network analysis as this is centred in the continental land mass. All cited countries, besides Serbia and FYROM, are the European Union (EU) members. 
As the paper illustrates the overview and analyses conducted so far, its purpose is mainly descriptive leaving thus action-oriented considerations for the subsequent research stages. The paper structure follows a deductive approach. Firstly, the global tendencies affecting the corridor development - in particular the indicators related to the trade, economy and demography, are taken into account. The central part of the paper is dedicated to the overview of the topics related to European scale. Hence, in addition to the clarification of the notion of transnationality (through its use in some of the most influential documents on the topic), the focus is on the overview of the Hamburg-Athens corridor - foreign investment initiatives in the area, its economic performance, and demographic forecasts, with a particular focus on the traffic balance along the corridor. Finally, the recommendations towards strengthening the capacities of local actors in the process of transnational cooperation are briefly indicated in the last section of the paper.

\section{GLOBAL TRENDS AND THEIR EFFECT ON EUROPEAN DEVELOPMENT}

As the topic of integrated spatial and transport development along the European corridors exceeds European importance only, i.e. it is affected by the global flows, this part of the paper briefly describes a scientific-based overview of the global tendencies with the impact on the Hamburg-Athens corridor. Specifically, the indicators such as trade, economy and demography are analysed more in detail. For such an analysis, the existing correlation between economic and demographic development as well as the trade activity acts as the base on which to sustain the analysis. ${ }^{4}$

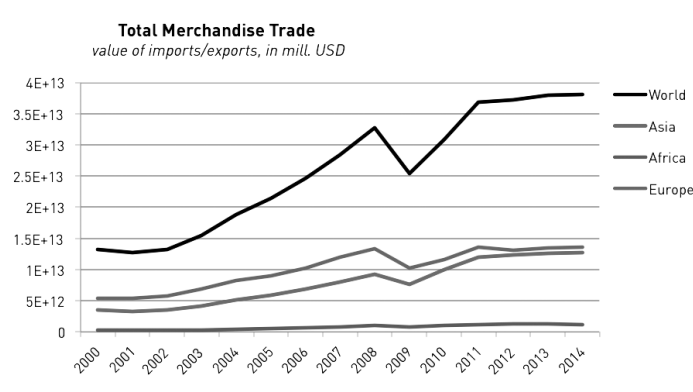

Figure 1. Merchandise trade, Global, 2000-2014. (Source: Author based on World Trade Organization, World Trade Report)

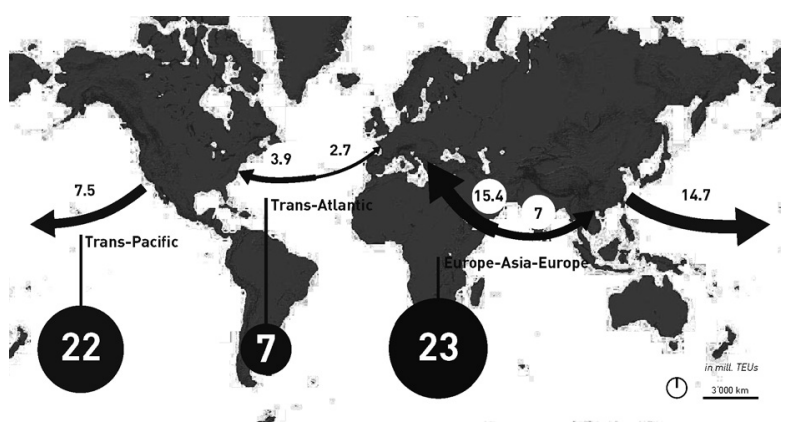

Figure 2. TEU traffic, Global, 2014. (Source: Author based on United Nations Conference on Trade and Development, Review of Maritime Transport) 


\section{Trade analysis}

Merchandise $^{5}$ activity has experienced a $0.3 \%$ growth worldwide from the last year-to-year data available (2013-2014) amounting to 38 trillion USD in total value. As Figure 1 depicts, a total merchandise trade experienced a decline in activity during the crisis years both world- and region wise. ${ }^{6}$ The fast recovery ( $21 \%$ from 2009-2010) coincides with the fast growth of the after crisis years. Trade growth from 2011 has remained quite constant at an average annual rate of $1.1 \%$ in the period 2011-2014. Other regions such as Asia and Europe have experienced a very similar growth pattern. The two regions have converged close to 13 trillion USD in terms of total merchandise value, having an average annual rate of $2.2 \%$ and $0.1 \%$ from 2011-2014, respectively.

Activity in Africa remains low with an average growth of $0.7 \%$ in the last 5 years, reflecting the high bundling of African economies to the Chinese demand plus the economic implications of commodity price contraction in oil and mineral net exporters such as Nigeria, Angola or South Africa. ${ }^{7}$ Moreover, its high poverty levels combined with a weak domestic demand slow further trade potentials in the region.

Although not having forecast data, recent studies predict a moderate trade growth in the coming years, based on the change in trade-income relationship. This causes a decline in trade elasticity, making trade not as responsive to income as it used to be in the 1990s or in the pre-crisis period. ${ }^{8}$

Within the maritime trade sector, $\mathrm{TEU}^{9}$ traffic is paid special attention to, as it plays a crucial role in the definition of the Corridor 22. Global containerised trade has reached 171 million of TEUs in 2014 (+5.3\% from 2013). Partly reflecting the recovery in the US and the improved prospects for Europe, containerised trade volumes carried on the Asia to Europe and Asia to North America routes are estimated to have increased by $7.5 \%$ and $6.3 \%$ from 2013 , respectively. Reflecting a weaker import demand in Asia, trade volumes on the backhaul journeys (opposite direction) remained weak. The strongest route is once again the Asia to Europe line, carrying 15.4 million of TEUs in 2014. The second largest is the line covering Asia to North America trade with 14.7 million TEUs carried (see Figure 2). ${ }^{10}$

From a share perspective, interregional trade, led by intra-Asia and South-South relations, accounted for $40 \%$ of global TEU volume, East-West lines for $30 \%$ and North-South traffic for $17 \%$ of total volume. TEU traffic prospects are not presented due to a lack of the data. However, with the above-mentioned figures, both economic and demographic, the correlation between these dimensions and 
trade might give hints on how trade activity will evolve in the foreseeable future. Most probably, the world will experience a gradual shift in global trade traffic from North-North relations to South-South links, as the main demographic and urban development growth will occur in low latitude regions.

\section{Economic analysis}

Two main aspects determine the current global economic situation: 1) the gradual slowdown in the Chinese economy, experiencing a structural transition from an investment-intensive model to a consumption-oriented one, and 2) the downturn in commodity prices triggered by weaker demand as well as over supply from the OPEC (Organization of the Petroleum Exporting Countries) members. ${ }^{11}$ Also, there is the approaching lift-off in interest rates by US and UK central banks, aiming to reach a $2 \%$ inflation rate in response to a sustained economic growth experienced in the past months. ${ }^{12}$

These factors are forcing the global economy to a stagnated period. As seen in Figure 3, global growth for 2015 is projected at 3.1\%, 0.3 \% lower than in 2014. Global GDP growth is expected to remain constant close to $4 \%$ until $2020 .{ }^{13}$ In this context, advanced economies ${ }^{14}$ are expected to pick up slightly maintaining interest rates generally low. This is brought by a modest recovery in the Euro Area (from $0.9 \%$ in 2014 to $1.5 \%$ in 2015 and $1.6 \%$ in 2016) supported by lower energy prices, monetary easing from the ECB since March $2015^{15}$ and the euro depreciation, falling by $11 \%$ against the US Dollar from the $1^{\text {st }}$ October 2014 until the $1^{\text {st }}$ October 2015. ${ }^{16}$ Europe is also expected to consolidate a modest growth from 2015 on. From the current $1.2 \%$ it is projected to stabilise at $1.9 \%$ until 2020 .

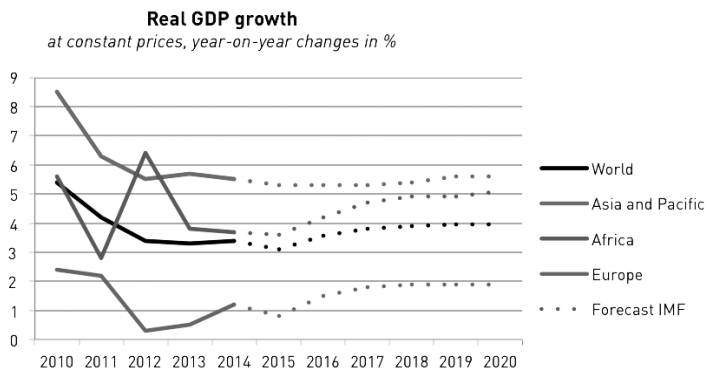

Figure 3. GDP rate, Global, 2010-2020. (Source: Author based on International Monetary Fund, World Economic Outlook October)

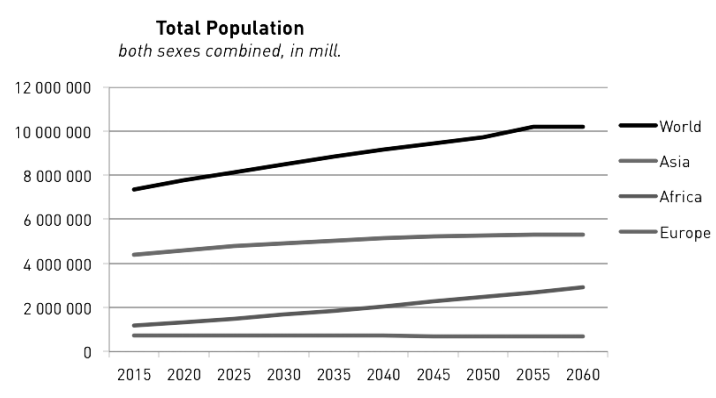

Figure 4. Total population, Global, 2015-2060. (Source: Author based on UN, World Population Prospects) 
In contrast to this, the activity in emerging markets and developing economies is projected to slow down for the fifth year in a row, primarily reflecting the weaker prospects for some large emerging market economies and oilexporting countries. Asia and Pacific region is expected to settle at around $5.5 \%$ growth until 2020 from the $8 \%$ it experienced back in 2010 (Fig. 3). Possible explanations for this downturn might be the systemic slowdown of Chinese demand, expected to grow under $7 \%$ for the first time since 2009 , at $6.8 \%$ in 2015 and $6.3 \%$ in 2016. The Chinese economy is expected to slow further, but with considerable uncertainties as to both the time frame for the slowdown and the full extent of the slowing. However, the implementation of structural reforms in the Asian economy and lower oil prices are expected to expand the consumer-oriented activities, partly buffering the slowdown. The decline in stock market valuations experienced last July ${ }^{17}$ is assumed to have only a modest effect on consumption reflecting modest household holdings. The recent decrease in interest rates by $0.25 \%$ denotes a clear effort from the China's Central Bank to cushion a deepening economic slowdown. ${ }^{18}$

\section{Demographic analysis}

A further key aspect regarding trade and economic development are demographic tendencies as consumption and labour productivity is induced by the living population and its age structure.

In 2015, the world population reached 7.3 billion and is projected to grow until 10.1 billion until 2050. All regions besides Europe are expected to experience demographic growth in the future. While Asia will add 896 million of people to its continent, Africa will contribute with an additional 1,700 million inhabitants to the world population. This means a growth rate of $20 \%$ and $144 \%$ from

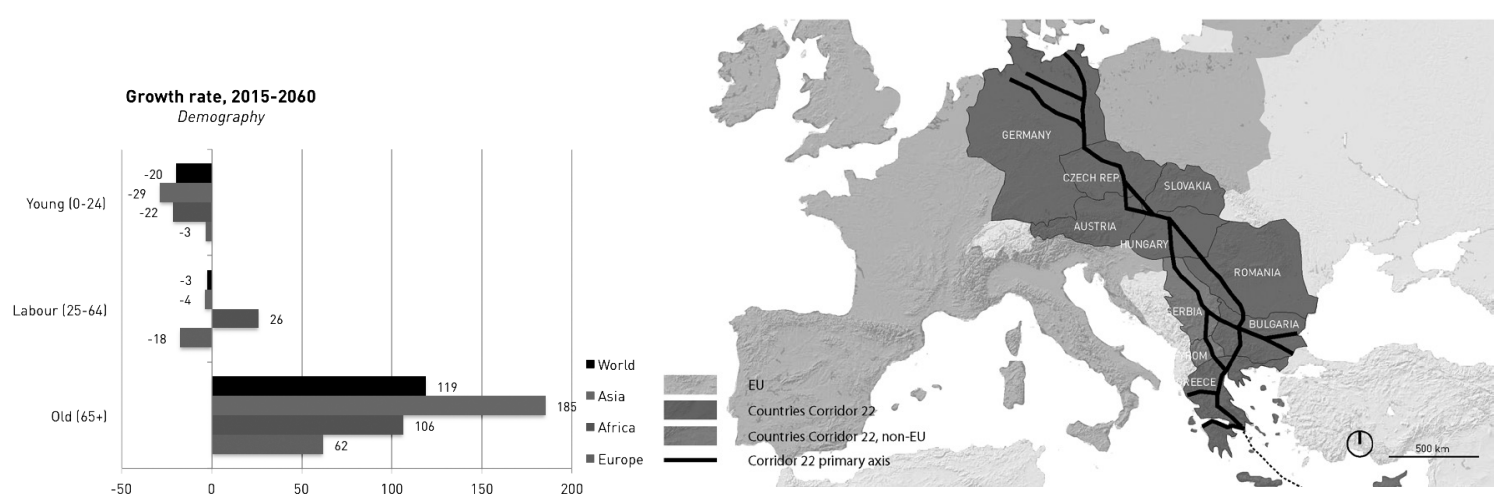


the present until 2050, respectively. In contrast to these figures, the European continent will shrink demographically by losing 50 million inhabitants, i.e. the population will decrease by $6.7 \%$ over the same period (see Figure 4 ). ${ }^{19}$

The slowdown in population growth is associated with a population aging, that is, as the population growth rate falls over time, the proportion of older people increases while that of younger persons decreases. For this purpose, three aging groups are considered: Young Population, ${ }^{20}$ Labour Force, ${ }^{21}$ and Old Population. ${ }^{22}$

In $2015,42 \%$ of the world population are under 24 years old. The labour force share and the old population share accounts for $49 \%$ and $8 \%$, respectively. The UN predicts that three main trends will determine the evolution of the mentioned age categories until 2060: 1) a gradual decrease in the young population group will decline to $34 \%, 2$ ) the maintenance in the labour force segment will reach $48 \%$, and 3 ) a sharp increase of old society segments will increase more than double in number. ${ }^{23}$

This trend is almost identical throughout the different regions in the world, as Figure 5 describes. The only difference relies on the trends magnitude and the labour force population in Africa. Whereas in all other regions this segment will decrease, in Africa it will experience a consolidated growth of $26 \%$ until $2060 .{ }^{24}$

These tendencies, combined with a projected rise in Life Expectancy (from 70 to 78 years until 2060 globally), will have tremendous implications in almost all segments of development. Regions where aging, labour decrease and rise in life expectancy meet will face high fiscal pressure on budgets as the number of beneficiaries of governments programmes (old people) will increase while tax revenues (labour force) will gradually decline, making it more difficult to finance existing debt. ${ }^{25}$ Moreover, public health spending is projected to more than double until 2060 in OECD countries from current $6 \%$ of GDP to around $13 \%$ of GDP, ${ }^{26}$ adding further pressure to government services. As a consequence, all sectors of everyday life will have to be readapted, from mobility to urban planning.

\section{TRANSNATIONAL INITIATIVES IN EUROPE}

After a brief overview of the global tendencies in terms of trade, economy and demography, it is interesting to observe their effect on the transnational initiatives in Europe. Hence, before proceeding with the specific analyses related to the Hamburg-Athens corridor as a territorial scope of the research, the findings from the key European documents on transnational cooperation will be briefly presented. 
Transnationality:

A key topic in European strategic documents

The topic of transnationality ${ }^{27}$ is referred as a key one in most of European documents on strategic development. It is strongly related to the previously mentioned macro-influences. More precisely, there are claims that transnationality appears as an outcome of the effects of globalisation, on the one hand, and network society, on the other. Firstly, due to the global capitalism, the national borders become looser thus enabling dynamic spatial relations - less control over the nation state territories, promotion of a multi-level governance system and reorganisation of territorial governance. Secondly, interconnected infrastructure networks are the incentive for the increase of interaction among the people in larger spaces across borders. ${ }^{28}$ In the following lines, the main findings from the key European documents on transnational cooperation are provided.

Within the Green Paper on Territorial Cohesion, the guidelines on how cohesion policy could improve territorial cohesion in future are presented. They can be summarised as follows: 1) promotion of a functional approach to integrated development of territories, 2) fostering the place-based policies through crosssectorial coordination of policies and multi-level governance from local to European level, 3) encouragement of the cooperation between territories to strengthen European integration, and 4) improvement of knowledge of territories, to guide their development. ${ }^{29}$

In Territorial Agenda of the European Union 2007, there is a clear demand for supporting the strengthening and extension of trans-European networks. In that terms, the following statements are of a particular importance: 1) mobility and accessibility are key prerequisites for economic development in all regions of the EU, 2) there is a need for an unhampered and socially fair access to information and communication technologies in all regions, in order to remove territorially induced barriers to accessibility, especially in peripheral and rural areas, and 3) there is a need to further explore and develop opportunities for decentralised, efficient, safe and environmentally friendly production of renewable energy. ${ }^{30}$

Territorial Agenda of the European Union 2020 promotes territorial integration in cross-border and transnational functional regions, because it: 1) can create a critical mass for development, diminishing economic, social and ecological fragmentation, building mutual trust and social capital, and 2) should be better embedded within national, regional and local development strategies. ${ }^{31}$

\section{European Corridor 22: Overview of the current state} The Corridor 22 is part of a wider programme named Trans-European Transport Network (TEN-T) promoted by the EC from 1996 onwards, involving 30 countries in Europe. The program aims at providing infrastructure upgrades 
for a smooth functioning of the European internal market, ensuring economic, social and territorial cohesion and improving the accessibility throughout the continental territory. ${ }^{32}$

Referred officially as an Orient/east-Med corridor, the Corridor 22 stretches from the North-eastern coasts of Germany to the South-eastern Greek lands (Figure 6). There is a number of goals related to the topic of corridor development, however they can be defined as follows: 1) to strengthen territorial cohesion across political instable countries, 2) to improve trade flows between North and South Europe mainly through ports infrastructures, and 3) to act as a backbone for future urban development potentials.

The Corridor 22 is a home to 163 million of people, a third of the EU's total population and covers 1.23 million $\mathrm{km}^{2}$ of land. The analysed countries sum up together $28 \%$ of total GDP in the EU. From a trade perspective, imports and exports of goods carried out along the region raised to $33 \%$ and $36 \%$ of total EU, respectively. Specifically, almost a half of all goods transported on rail within EU borders occurred in the analysed perimeter. ${ }^{33}$

\section{Trade and infrastructure overview}

Import and export of goods along the Corridor 22 amounted to 4.1 trillion USD in total merchandise value ${ }^{34}$, that is $11 \%$ of the global merchandise value traded. Regarding the modal split, ${ }^{35} 22 \%$ of the goods transported in the corridor region used rail transport. This is a much higher share than in the EU, where rail share amounts to $14 \%$. Within the countries, Serbia is the leading rail transporter having more than $80 \%$ of the goods on the tracks. Greece and Cyprus have the lowest rail shares in the region with $3 \%$ and $0 \%$, respectively (Figure 7).

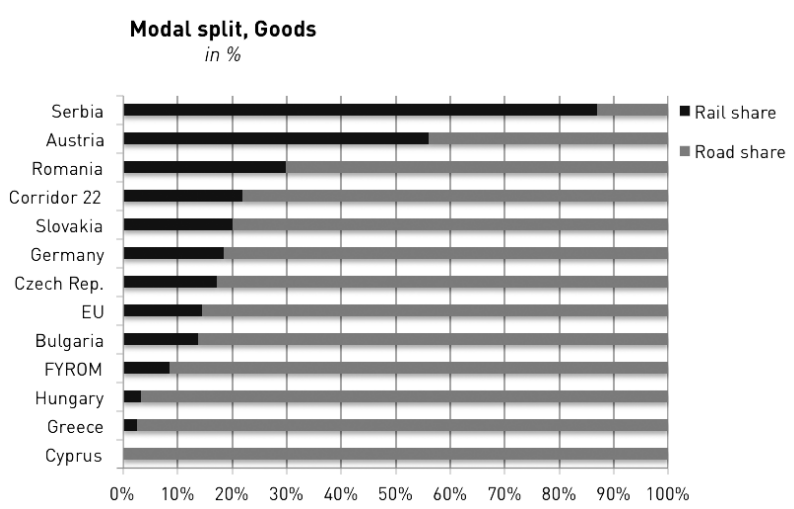

Figure 7. Modal split of goods, Corridor 22, 2014.

(Source: Author based on KNOEMA, Smarter Research With All Statistics in your Hand, 2011-2015)

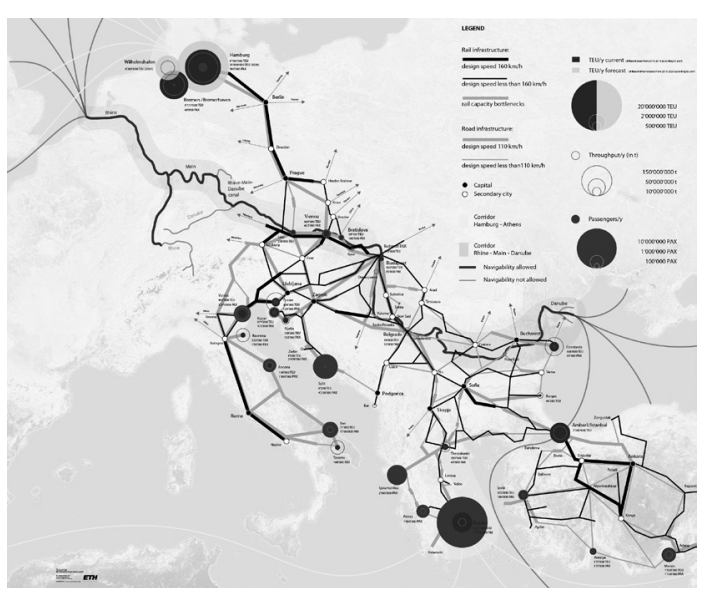

Figure 8. Infrastructure analysis, Corridor 22, Current state. (Source: Author based on various sources) 
It is worth noticing that the abovementioned figures partly reflect the infrastructure network condition in each country. For this reason, ports, rail and road infrastructures where analysed both in the Corridor 22 countries and in its surrounding neighbours. Figure 8 shows the result of the network analysis. Two main axes serve as reference for the matter: the North-South system, running from Germany to Greece and overlapping the known Corridor 22 route, and the east-west water network connecting the Black Sea on the east with the Atlantic Ocean on the west. The intersection of both systems, around the ViennaBudapest-Belgrade triangle, is of particular importance for this matter.

Main findings with regard to the traffic overview along the Hamburg-Athens corridor are explained as follows:

1. There is an asymmetry in the freight distribution through the maritime transportation mode. Sea freight is mainly concentrated in the North ports of Hamburg and Bremerhaven. At the same time, maritime passenger figures are low in Germany. In contrast to this, both in Greece and the Adriatic ports, the main flows using ports are the passengers, denoting a much more tourist-oriented economy than in the North.

2. There is unevenness in infrastructure development, reflecting the past of Eastern Europe. High-speed train lines are in operation in developed countries as Germany, Austria and Italy, but completely lacking in Balkan countries. Moreover, a density in the high-level road systems is also lower in Romania and Bulgaria compared to many of the Northern countries.

3. The Corridor 22 has a $51 \%$ lower performance than EU countries when weighting following indicators together: Imports/Exports of goods, Goods transported on rail/road, passenger transported on rail/road and rail/road network density (see Table 1).

\begin{tabular}{|c|c|c|c|c|c|c|c|c|}
\hline & $\begin{array}{l}\text { IMPORTS } \\
\text { OF GOODS } \\
\text { BOP USD }\end{array}$ & $\begin{array}{l}\text { EXPORTS } \\
\text { OF GOODS } \\
\text { BOP USD }\end{array}$ & $\begin{array}{c}\text { GOODS } \\
\text { ON RAIL } \\
m i 77 . \quad T / k m\end{array}$ & $\begin{array}{c}\text { PASSENGERS } \\
\text { ON RAIL } \\
\text { mi } 77 . \\
\text { pax } / \mathrm{km}\end{array}$ & $\begin{array}{l}\text { GOODS } \\
\text { ON ROAD } \\
\text { mi } 77 \text {. } \\
\text { pax/ km }\end{array}$ & $\begin{array}{c}\text { PASSENGERS } \\
\text { ON ROAD } \\
m i 77 . \\
\text { pax } / \mathrm{km}\end{array}$ & $\begin{array}{c}\text { RAIL } \\
\text { NETWORK } \\
\text { DENSITY } \\
\mathrm{km} / 100 \mathrm{~km}^{2}\end{array}$ & $\begin{array}{c}\text { ROAD } \\
\text { NETWORK } \\
\text { DENSITY } \\
\mathrm{km} / 100 \mathrm{~km}^{2}\end{array}$ \\
\hline AUSTRIA & $165 ' 185$ & $165^{\prime} 071$ & $21^{\prime} 683$ & $10 ’ 353$ & $16^{\prime} 997$ & $85^{\prime} 600$ & 6.0 & 139.1 \\
\hline BULGARIA & $32 ' 642$ & $29^{\prime} 520$ & $2 ’ 850$ & $1 ' 876$ & $17 ’ 943$ & $10 ’ 843$ & 3.7 & 18.0 \\
\hline CYPRUS & $5 ’ 859$ & $2 ’ 523$ & $11^{\prime} 423$ & 6’907 & 924 & 7’200 & & 140.8 \\
\hline CZECH REP. & $120^{\prime} 668$ & $129^{\prime} 678$ & 497 & $155^{\prime}$ & $54^{\prime} 830$ & $80 ’ 304$ & 12.3 & 169.2 \\
\hline FYROM & $5^{\prime} 634$ & 3’167 & $105 ' 894$ & $80 ’ 210$ & 5’381 & 1'640 & 2.8 & 55.4 \\
\hline GERMANY & 1'160'660 & 1'440'130 & 538 & 1'413 & 468’900 & 994’312 & 9.6 & 184.7 \\
\hline GREECE & $52^{\prime} 582$ & $29^{\prime} 678$ & 1'179 & 5,887 & $20 ’ 597$ & $119^{\prime} 500$ & 2.0 & 90.7 \\
\hline HUNGARY & $91^{\prime} 406$ & $96 ’ 175$ & $11 ’ 200$ & 4’148 & $34^{\prime} 528$ & $71 ' 685$ & 8.7 & 222.0 \\
\hline ROMAN I A & 65,578 & $58 ’ 292$ & 2’955 & 801 & $26 ’ 347$ & $28 ’ 340$ & 4.7 & 48.5 \\
\hline SERBIA & $19^{\prime} 528$ & $14^{\prime} 010$ & 7’262 & 4'863 & 446 & 4'151 & 4.6 & 50.0 \\
\hline SLOVAKIA & 79'841 & $85^{\prime} 522$ & & & $29^{\prime} 045$ & $31 ' 568$ & 7.5 & 90.2 \\
\hline
\end{tabular}

Table 1. Trade indicators, Corridor 22, 2014. (Source: Author based on various sources) 
4. There is a need to involve the Black Sea and Turkey as the actors relevant for the planning of the Corridor. The Black Sea is known to hold up vast oil reserves, which have been little exploited until the date. Studies predict at least 184 billion cubic meters (bcm) of oil reserves in the offshore coast of Romania and Bulgaria. ${ }^{36}$ By investing in such explorations, South-western Europe could boost the long-standing quest to make itself less reliant on Russian imports. Turkey is also a relevant actor in the scene. Besides being a NATO member, and thus already immerse in West alliances, it may act as a bridge between rich oil reserves in the Caspian Sea and Europe to further diminish Russian dependency. Moreover, the current migrant crisis, which induced 400,000 refugees to cross Turkey's border into Greece in $2015,{ }^{37}$ urge for a better coordination and involvement between the EU and the Asian country.

\section{Economic overview}

From an economic point of view, the Hamburg-Athens corridor and its catchment area is consolidating an economic recovery after the financial crisis. In 2014, it experienced $1.36 \%$ GDP growth and is expected to keep the pace stabilising at $2.5 \%$ until 2020. These figures are lower than the overall global GDP but certainly better if compared to Europe. In fact, the Corridor 22 just overpassed the Europe average and is expected to maintain the trend in the next 5 years (see Figure 9). There are considerable differences within the corridor members. In fact, only 4 out of the 11 countries did not enter the negative growth rates in the last five years. While Greece and Cyprus dropped until - 8 \% rates, Germany, Austria, Hungary and Bulgaria maintained their GDP figures in the positive area. As a consequence, the slowest recovery is projected to occur in Greece and Cyprus, staying in negative figures until 2016.

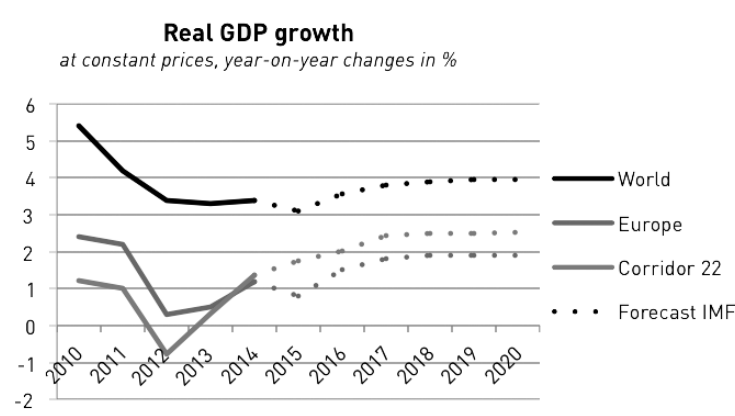

Figure 9. GDP rate, Regional, 2010-202. (Source: Author based on International Monetary Fund, World Economic Outlook October)

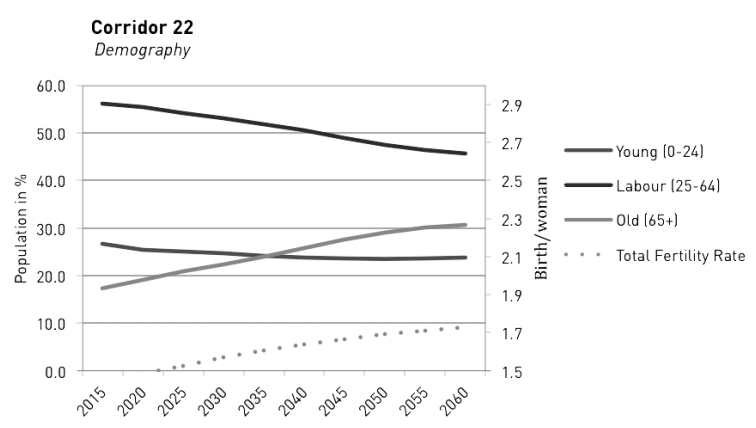

Figure 10. Age categories, Corridor 22, 2015-2060. (Source: Author based on UN, World Population Prospects) 
Following economic indicators were compared between the Corridor 22 countries and EU as a whole: Total GDP, GDP/capita, Purchasing Power Parity (PPP), GDP growth rate, Unemployment rate, Population density, Urban population share and Global Competitiveness index. The analysis concluded that Corridor 22 countries perform on average $21 \%$ lower than EU nations (see Table 2).

\begin{tabular}{|c|c|c|c|c|c|c|c|c|}
\hline & $\begin{array}{l}\text { TOTAL GDP } \\
\text { bi77. EUR }\end{array}$ & $\begin{array}{l}\text { GDP/capita } \\
\text { EUR/inh. }\end{array}$ & $\begin{array}{c}\text { PPP } \\
\text { USD/inh. }\end{array}$ & $\begin{array}{c}\text { GDP } \\
\text { growth rate } \\
\%\end{array}$ & $\begin{array}{c}\text { UN- } \\
\text { EMPLOYMENT } \\
\text { RATE } \\
\%\end{array}$ & $\begin{array}{l}\text { POPULATION } \\
\text { DENSITY } \\
\%\end{array}$ & $\begin{array}{c}\text { URBAN } \\
\text { POPULATION } \\
\% \\
\%\end{array}$ & $\begin{array}{c}\text { GLOBAL } \\
\text { COMPETITIVNESS } \\
\text { INDEX } \\
\text { Ranking 非 } \\
\end{array}$ \\
\hline AUSTRIA & 404 & $45^{\prime} 410$ & $45^{\prime} 411$ & 0.4 & 5.0 & 102 & 66 & 21 \\
\hline BULGARIA & 51 & 6'786 & $17^{\prime} 115$ & 1.7 & 12.5 & 67 & 73 & 54 \\
\hline CYPRUS & 20 & $23^{\prime} 027$ & $27^{\prime} 986$ & -2.2 & 16.6 & 123 & 67 & 58 \\
\hline CZECH REP. & 185 & $17^{\prime} 475$ & $28^{\prime} 446$ & 2.0 & 6.4 & 136 & 73 & 37 \\
\hline FYROM & 10 & 4'566 & $13{ }^{\prime} 204$ & 3.7 & 29.0 & 83 & 57 & 63 \\
\hline GERMANY & 3'538 & $41^{\prime} 669$ & $44^{\prime} 741$ & 1.6 & 5.3 & 231 & 75 & 5 \\
\hline GREECE & 228 & $20 ’ 240$ & $25^{\prime} 753$ & 0.8 & 25.8 & 85 & 77 & 81 \\
\hline HUNGARY & 120 & $12^{\prime} 397$ & $24^{\prime} 336$ & 3.6 & 8.2 & 109 & 70 & 60 \\
\hline ROMANIA & 187 & 8’217 & 19’397 & 2.8 & 7.2 & 89 & 54 & 59 \\
\hline SERBIA & 39 & 5,465 & $12^{\prime} 605$ & -1.8 & 21.6 & 82 & 55 & 94 \\
\hline SLOVAKIA & 93 & $16^{\prime} 396$ & $27^{\prime} 665$ & 2.4 & 13.9 & 112 & 54 & 75 \\
\hline
\end{tabular}

Table 2. Economic indicators, Corridor 22, 2014. (Source: Author based on various sources)

\section{Demographic overview}

Demographic figures in the region show a declining trend both in absolute terms and in labour force categories. Whereas the world will grow in absolute terms, the Corridor 22 and Europe will shrink by $15 \%$ and $7 \%$, respectively. ${ }^{38}$ What is more worrying, the labour force in the corridor countries is projected to downward in the coming decades stronger than in Europe. Although shrinking in three levels (World, Europe, Corridor 22), it is in the last two where the decline is more acute. If 92 million of people are now aged between 25 and 64 in the research context, it will be only 63 million in 2060. Again, global trends are reflected also in the corridor system. While old population segments will keep growing at a fast pace ( $+76 \%$ by 2060 ), young age categories will barely maintain its share in total population (-10\% by 2060) (Figure 10). Two indicators counterbalance the negative demographic prospects for the corridor: 1) a very high Life Expectancy set at 77 years (World average is 70.4), and 2) a slight upturn in Total Fertility rate from the current 1.4 children/woman to 1.7 in 2060.

Hence, these figures urge the Corridor 22 and Europe authorities to incentive policies supporting natality. Moreover, immigration should be seen as an opportunity to counterbalance the shrinking European labour force and thus ease public expenditure pressure on retirement pensions.

Foreign investment initiatives: Some future prospects As mentioned previously, global decisions tend to have regional and local impacts in an interconnected world. Foreign investment capital may be one of the most visible translators of this mechanism. A brief overview of the latest initiatives of foreign investment in the region is given in the following sections. 
On September 2013, Chinese President Xi Jinping announced his "Silk Route" initiative in Kazakhstan while on tour on Central Asia. Officially called "Belt and Road" this vision is becoming the focus of Chinese diplomacy in the last years. The vision aims at creating an interconnected transport network that will promote development, boost intercontinental trade between Asia and Europe, attract foreign investment, and thereby enhance stability and security for states in a historically turbulent region. ${ }^{39}$ Connectivity would include investment in port infrastructure and modernisation of facilities throughout the route. ${ }^{40}$

The "Belt and Road" strategy has deep interests in Eastern Europe. In fact, the Balkan region is seen by the Chinese authorities as the European gateway for their products into the rich North Europe. ${ }^{41}$ Hence, Southeast Europe might become one of the most important Chinese funding receptors in the coming years. There are several reasons for this: 1) the will of China to cut sea freight travel time by enhancing port infrastructures and embed intermodal processes in the supply chain, 2) the interest to diversify Chinese trade partners by improving transport corridors to Europe, and 3) the strategic aim of gaining a political influence in the region.

The projects from Chinese companies embrace all kind of sectors - from transport to mining industry. Only a selection will be mentioned in this paper. More precisely, in 2009 Chinese carrier Cosco acquired the management rights of a half of Piraeus port in Athens in a 500 million EUR deal. Business activity has tripled since then. ${ }^{42}$ China has already expressed interest in purchasing the port of Thessaloniki, Greece's state-run railway network and more cooperation in airport, road and other infrastructure developments. As the country constitute the most eastern part of the West, such initiatives can be seen as a starting point of the continuation and expansion of Beijing's presence in the old continent. ${ }^{43}$

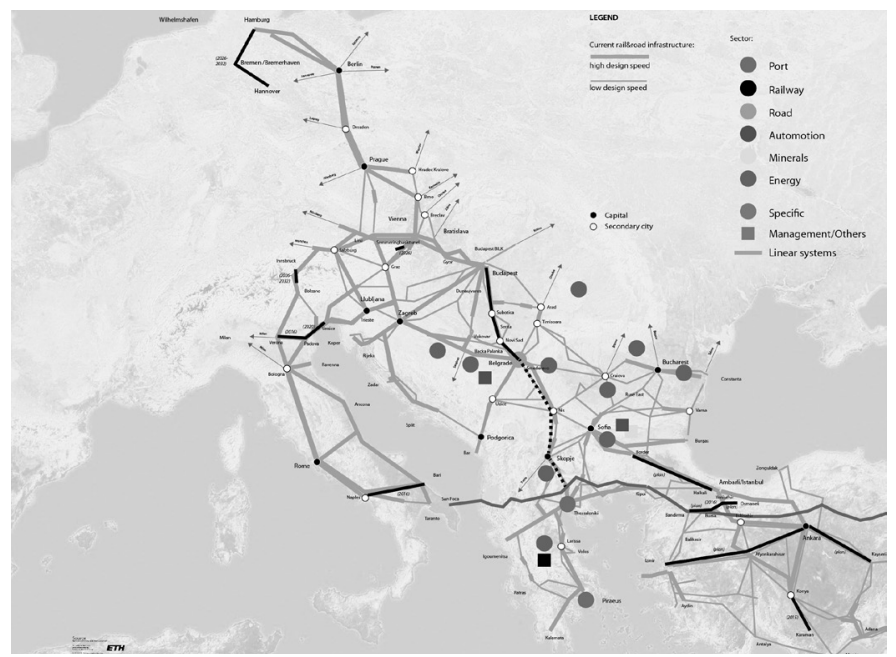

Figure 11. Planned projects, Corridor 22. (Source: Author based on various sources) 
In 2011, China also launched a forum for cooperation with Central and East European countries, the " $16+1 " .{ }^{44}$ This includes 11 EU countries (Bulgaria, Croatia, the Czech Republic, Estonia, Hungary, Latvia, Lithuania, Poland, Romania, Slovakia, Slovenia) and 5 EU candidates (Albania, Bosnia and Herzegovina, FYROM, Montenegro and Serbia). Although vastly different culturally, linguistically, and in terms of religion, these countries are united in their quest for Chinese investment. ${ }^{45}$ They are also all former communist states and thus share some common historical experience with China. Within this forum, Chinese leaders agreed on assisting Hungary and Serbia in upgrading the railway between Budapest and Belgrade. ${ }^{46}$ Moreover, China agreed with Romania that it would assist in building a high-speed railway between the Black Sea port of Constanta and (eventually) Vienna. ${ }^{47}$

Lastly, energy distribution can become crucial, both in terms of acquiring energy independence and fostering development across the region. Greece can be a key actor due to its geostrategic location. One particular project stands out in this regard; the Trans Adriatic Pipeline (TAP) ${ }^{48}$ This project can enhance the role played by Greece, to become the energy distributor in the region. In fact, branches from the TAP to Bulgaria, Croatia, and FYROM are already being studied as to supply gas to the corridor countries. Some of the most important future projects are indicated in Figure 11.

\section{THE ROLE OF LOCAL STAKEHOLDERS IN TRANSNATIONAL DYNAMICS}

All the before-mentioned infrastructure projects require a considerable amount of political as well as financial support. In the next section, the role of local governments in transnational networking is looked more closely arguing that such urban networks facilitate local institutions to gain influence and visibility in their own social and spatial context.

For this purpose it is necessary to first elucidate how local governments are becoming more prominent in the wake of deciding on transnational projects. Given the new relationship between politics and economics, ${ }^{49}$ cities are obliged to take on an international dimension. Three decades of post-Fordist transition have forced the states to adapt to the new economic order and to make their cities the new sites of economic competition. Hence, the imperative for internationalisation is necessary for the "survival" of major cities. ${ }^{50}$ This on-going recalibration process is contributing to a change in spatial scales of social-economic regulation. As a consequence, from the 1990s on, cities became involved in international relationships, ${ }^{51}$ among all the setting up of inter-city cooperation networks. ${ }^{52}$ 
In this regard, the adoption of the Maastricht treaty, ${ }^{53}$ and with it the notion of subsidiarity, and the establishment of the Committee of the Region as a part of the EU's institutional structure led to further opportunities for the local government involvement in Europe's decisions. This marks a transition from the territorial model of administration, which characterised almost all the western cities up to the second third of the $20^{\text {th }}$ century, to urban governance systems, based on collaboration between major cities with a view in gaining easier access to global markets and international visibility. ${ }^{54}$

In order to reach influence in the international arena, cities have to demonstrate their capacity to form networks of cooperation among them. It's the membership to these transnational networks that make cities international and not the other way around. ${ }^{55}$ And it is this membership that poses a direct challenge to the "dominance of the state". ${ }^{56}$ As a consequence, cities (and not states!) have to gradually gain the influence and pre-eminence in European policymaking. This is especially critical in regions where multiple nations collide in a relatively small area, such as Europe. In this context, the cross-border projects become increasingly important as transport networks and economic areas neglect the administrative borders of states.

For this reasons, the major cities along the Corridor 22 should embed, or strengthen, its local institutions in transnational networks. The cities, and along them the local stakeholders, have to become the real policy drivers in the coming future on the basis of horizontal cooperation with its counterparts along the region. This could mean to create a transnational network of cities within the Corridor 22. This would further create a common round table around the most relevant cross-border projects in the region and a stronger position towards requiring assistance and support in European institutions. Several reasons on why cities should integrate in such networks are elucidated as follows:

1. Securing the funding and financial capabilities by EU programmes. The members of transnational networks have easier access to the European subsidies. These financial sources play a significant role as funding projects from national government decreases as a response to economic crisis and austerity measures. This is especially the case for localities with areas of deprivation or in need of regeneration as in the Balkan region. The funding provided by the European programmes here can help improving the local economic conditions. Moreover, these institutionalised networks are likely to involve private operators allowing for possible sponsorship to specific initiatives. ${ }^{57}$

2. Lobbying the 7everage in European institutions. The British Local Government Association, ${ }^{58}$ estimated that $70 \%$ to $80 \%$ of the legislation that the local authorities are required to implement originates in 
Europe. ${ }^{59}$ This means that the transfer in competences from the national to the supra-national level strives for better multi-level lobbying. The lobbying through networks is generally more successful than through individual actors, because the EC prefers to deal with groups who can claim to be representative of a wider body of actors. ${ }^{60}$ Thus, by lobbying collectively, members gain credibility, which in turn increases the chances of success.

3. Knowledge sharing among members. It is precisely the transfer of experience that provides the network's added value. Local stakeholders can use these networks for sharing and accessing knowledge, experience and best practice. In fact, lessons and experiences learnt through transnational networks are applied to local services, acting as a tool for "policy learning". ${ }^{61}$ These networks permit local entities to acquire innovative policy solutions, which would not have been considered had they been learning from national authorities.

4. Promoting the local identities throughout network members. By being within a transnational network, cities are able to seek an international profile to secure inward investments, tourism and promote local economic benefits. In addition to these practical benefits, an increased identity means increased visibility and recognition beyond the local borders. ${ }^{62}$ This achievement is considerably easier if being part of a wider international community where good-practices and experiences can be shared.

It is believed that the membership in such transnational networks by local stakeholders is not only crucial and necessary given the socio-economic context Europe is immerse in, but also will be on the own benefit of the member cities.

\section{CONCLUDING REMARKS}

In the preceding analysis, it has been attempted to give an overview of the ongoing research on Spatial and Transport Development in European Corridors: Example Corridor 22, Hamburg-Athens, based on socio-economic tendencies and insights into institutional mechanisms at the local level. Three main conclusions can be drawn from this writing.

Firstly, there are negative outlooks in terms of economic and demographic development in the Corridor region. Albeit the high volatility of economic prospects issued by renowned international institutions, it is reasonable to foresee a decline or at least maintenance in GDP growth rates in the next 5 years. Demography tendencies are much more stable and credible due to its systemic origin. In this regard, corridor countries will shrink both in total terms and in labour force segments in the next decades. As a consequence, trade will be impacted due to its correlation with economy and demography. 
Secondly, there is a clear need of using foreign mechanisms as a tool to balance negative socio-economic outlooks in the region. Chinese investment interests in South-eastern Europe have been highlighted in this regard. This can be seen as an opportunity for under-developed countries in a weak economic context to receive funding with the aim to upgrade their respective infrastructure network. While Chinese involvement can be seen with good eyes, the Balkan countries should try to diversify foreign investment members as China is immerse in a systemic transition from its economic model. Winks to other BRICS ${ }^{63}$ members with better outlooks (i.e. India) or emerging economies with interests in the European market could be an alternative. In terms of demography, immigration should be seen as the only hope for both the Corridor 22 and Europe to counterbalance the shrinking trend. The region should recognise the potential of being neighbour to the most fast growing region in the world (i.e. Africa). It should also see the actual refugee crisis as an opportunity to gain young population and future labour force for the coming generations.

Thirdly, the urge to set local government as the real drivers of economy and growth in a context were state institutions are downscaling their policy leverage in favour of regional and local entities. In this regard, it has been argued that the involvement of local governments in European transnational networks is an optimal way both to secure funding opportunities and create a wide contact pool on which to build further cooperation projects across borders. Corridor cities should come together and create a regional network in which to create a common strategy for transnational projects. With a common position, cities should obtain credibility in gaining access to European structures. (ARL). This German institution established an international working group (IAK) with the aim of providing various expertise (in terms of both academic and practical experience, mainly in spatial planning and development, as well as in transportation domain) in order to define the mechanisms for sustainable transnational cooperation. The Swiss Federal Institute of Technology (ETH) is a member of the IAK and is responsible for its leading and coordination. For more information visit http://www.arl-net.de.

2 European Commission, Mobility and Transport - Trans-European Transport Network TENtec, accessed October 5, 2015, http://ec.europa.eu/transport/infrastructure/tentec/tentec-portal/site/en/ abouttent.htm. in 2005 by the EU. According to this classification there were in total 25 corridors of European importance. See: European Communities, Trans-European Transport Network - TEN-T priority axes and projects (Luxembourg: Office for Publications of the European Communities, 2005). In 2011, new and simplified classification was made - Core Network Corridors, according to which we can differentiate 11 most important axes in Europe. The corridor Hamburg-Athens or Orient/east- 
Med is one of these corridors. See: European Commission (EC), TEN-T Core Network Including Core Network Corridors (Brussels: EC, 2011).

Funda Yercan and Turkay Yildiz, ,International maritime trade and logistics, “ in Maritime Logistics, eds. Dong-Wook Song and Photis M. Panayides. (London: Kogan Page, 2012).

Includes goods traded, not services nor capital transfers and foreign investments.

World Trade Organization, World Trade Report 2014 - Trade and development: recent trends and the role of the WTO (Geneva: World Trade Organization, 2014).

See: OPEC, Monthly Oil Market Report - 12 October 2015, accessed October 18, 2015, http:// www.opec.org/opec_web/static files_project/media/downloads/publications/MOMROctober2015. pdf; KPMG, Mining in Africa Towards 2020, accessed October 19, 2015, https://www.kpmg. com/Africa/en/IssuesAndInsights/Articles-Publications/Documents/Mining\%20in\%20Africa $\% 20$ towards $\% 202020 . p d f$.

Cristina Constantinescu, Aaditya Mattoo and Michele Ruta, The Global Trade Slowdown: Cyclical or Structural? (IMF Working Paper, 2015), accessed October 18, 2015, https://www.imf.org/ external/pubs/ft/wp/2015/wp1506.pdf.

TEU (Twenty-foot Equivalent Units) is the widely used freight container due to its standardised dimension. It measures $20 \mathrm{ft} \times 8 \mathrm{ft} \times 8 \mathrm{ft} 6$ in, with $38.5 \mathrm{~m}^{3}$ of volume capacity.

United Nations Conference on Trade and Development, Review of Maritime Transport 2015 (Geneva: United Nations Publication, 2015).

World Bank Group, Global Economic Prospects June 2015 - The Global Economy in Transition (Washington: The World Bank, 2015).

R.A., "The Fed's plan to hike interest rates", The Economist, August 31, 2015, accessed September 26 2015, http://www.economist.com/blogs/economist-explains/2015/08/economist-explains-21.

International Monetary Fund, World Economic Outlook October 2015 - Adjusting to Lower Commodity Prices (Washington: International Monetary Fund, 2015).

IMF classification considers the following categories: Advanced economies, Euro Area, Europe, Emerging markets, Developing economies, Asia and Pacific, sub-Saharan Africa and Africa.

P.W. \& C.R., „Getting the machines revving“, The Economist, London, March 9, 2015, accessed October 2, 2015, http://www.economist.com/blogs/freeexchange/2015/03/quantitative-easing-andeuro.

European Central Bank, Euro exchange rates USD, accessed October 22, 2015, https://www.ecb. europa.eu/stats/exchange/eurofxref/html/eurofxref-graph-usd.en.html.

Charles Riley and Sophia Yan, "China's stock market crash...in 2 minutes," CNN, Hong Kong, August 27, 2015, accessed September 10, 2015, http://money.cnn.com/2015/07/09/investing/chinacrash-in-two-minutes/.

Bloomberg News, „China Cuts Interest Rates as Policy Divergence With U.S. Widens“, Bloomberg, October 23, 2015, accessed October 24, 2015, http://www.bloomberg.com/news/ articles/2015-10-23/china-cuts-interest-rates-reserve-ratios-to-counter-slowdown.

United Nations, World Population Prospects - Key findings \& advance tables - 2015 Revision (New York: United Nations Publication, 2015).

Aged 0-24, both sexes combined, UN, World Population Prospects.

Aged 25-64, both sexes combined, UN, World Population Prospects.

Aged 65+, both sexes combined, UN, World Population Prospects.

UN, World Population Prospects.

UN, World Population Prospects.

Institute of Medicine Committee on the Long-Run Macroeconomic Effects of the Aging U.S. Population, Aging and the Macroeconomy (Washington: National Academy Press, 2012).

OECD, What future for Health Spending?, accessed on October 17, 2015, http://www.oecd.org/eco/ growth/aaaaaawhatfuture.pdf.

Due to the active expansion of collaboration across national border, there is a number of various terms used in recent time in order to refer to the topic of transnationality. Some of these are: crossborder, interregional, transnational, transfrontier, transboundary, transborder, trans-European, 
supranational, and intergovernmental. Nevertheless, the cooperation across large multi-national spaces is referred to as transnational cooperation. For further explanations of the mentioned terms see: Stefanie Dühr, Claire Colomb and Vincent Nadin, European Spatial Planning and Territorial Cooperation (Abingdon, Oxon: Routledge, 2010), 30.

Ibid., 16.

Commission of the European Communities, Green Paper on Territorial Cohesion - Turning Territorial Diversity into Strength (Brussels: Commission of the European Communities, 2008). IMMUDTC (Informal Ministerial Meeting on Urban Development and Territorial Cohesion), Territorial Agenda of the European Union: Towards a more competitive and sustainable Europe of diverse regions. Agreed on the occasion of the Informal Ministerial Meeting on Urban Development and Territorial Cohesion, 24-25 May 2007, Leipzig, accessed June 11, 2012, http://www.infocooperare.ro/Files/Territorial $\% 20$ Agenda $\% 20$ of $\% 20$ the $\% 20$ European $\% 20$ Union_20093195.pdf.

IMMUDTC (Informal Ministerial Meeting on Urban Development and Territorial Cohesion), Territorial Agenda of the European Union: Towards an inclusive, smart and sustainable Europe of diverse regions. Agreed at the Informal Ministerial Meeting of Ministers responsible for Spatial Planning and Territorial Development, 19 May 2011, Hungary, accessed June 12, 2012, ntccp-udg. eu/system/files/TA2020.pdf.

European Commission, Mobility and Transport.

KNOEMA, Smarter Research With All Statistics in your Hand, 2011-2015, accessed June 9, 2015, http://knoema.de.

World Trade Organization, World Trade Report 2014.

Share of each mode of transport (i.e. maritime, rail, road, air) in absolute figures or as a percentage of total demand for passenger or goods transported. Here, only rail and road are considered.

ITE Oil \& Gas, „Black Sea offshore production in 2015 - a route to energy independence?“, April 1, 2015, accessed October 13, 2015, http://www.oilgas-events.com/market-insights/ georgia-romania-russia-turkey/black-sea-offshore-production-in-2015-a-route-to-energyindependence-/801781383.

Ron Redmond, „Refugee sea arrivals in Greece this year approach 400,000“, October 2, 2015 , accessed October 13, 2015. http://www.unhcr.org/560e63626.html.

UN, World Population Prospects.

For this purpose, China plans to invest in air, rail, road, port and energy infrastructures along Central Asian and European countries. Moreover, a maritime component of the main "Silk Route" was launched in 2014. This branch is expected to stretch across Southeast Asia, the Indian Ocean, Persian Gulf and the Mediterranean. See: Theresa Fallon, ,,The New Silk Road: Xi Jinping’s Grand Strategy for Euroasia“, American Foreign Policy Interests, August 2015, accessed October 23, 2015, http:/www.ou.edu/uschina/texts/Fallon.2015.AFPI.New Silk Road.pdf.

ASEAN - China Centre, ,Regulations“ (speech by Chinese President to Indonesian Parliament, Jakarta, October 2, 2013), accessed October 17, 2015, http://www.asean-china-center.org/ english/2013-10/03/c 133062675.htm.

Loïc Poulain, "China’s New Balkan Strategy”, Central Europe Watch 2 (2011).

Helena Smith, „Chinese carrier Cosco is transforming Piraeus - and has eyes on Thessaloniki“, The Guardian, June 19, 2014, accessed March 20, 2015, http://www.theguardian.com/world/2014/ jun/19/china-piraeus-greece-cosco-thessaloniki-railways.

George N. Tzogopoulos, „How Greece sees China’s international role as client and partner“, Global Times, February 2, 2013, accessed October 13, 2015, http://www.globaltimes.cn/content/762681. shtml.

6 out of 11 countries of Corridor 22 are included in this forum.

Marta Golonka, Partners or Rivals? Chinese Investments in Central and Eastern Europe (Warsaw: Central \& Eastern European Development Institute, 2012).

MTI, „Hungary, Serbia, China agree on upgrading Budapest-Belgrade railway“, Politics.HU, November 26, 2013, accessed on October 22, 2015. http://www.politics.hu/20131126/hungary- 
serbia-china-agree-on-upgrading-budapest-belgrade-railway/.

Hu Qingyun, „China to help Romania high-speed rail“, Global Times, November 26, 2013, accessed on October 1, 2015, http://www.globaltimes.cn/content/827633.shtml.

This gas pipe crosses Northern Greece, Albania and the Adriatic Sea before coming ashore in Southern Italy to connect to the Italian natural gas network. The pipeline will connect in the Turkish border to the Trans-Anatolian pipeline (TANAP) allowing the flow of natural gas from the Shah Deniz II field, off the coast of Azerbaijan. Its initial capacity is $10 \mathrm{bcm}$ (billion cubic meter) of gas per year (approximately the energy consumption of 7 mill. household in Europe) but able to double if needed. See: Trans Adriatic Pipeline, Baar, June 2015, accessed on October 25, 2015. http://www.tap-ag.com/assets/08.about us/english/TAP Corporate Brochure June $\% 20$ 2015 EN Updated.pdf.

Zygmunt Bauman, Globalization - The Human Consequences (New York, Columbia University Press, 1998). and Eurocities (1990-2005) (International Journal of Urban and Regional Research, 2010).

Three different international relationships can be identified. (1) Direct links with local authorities in other countries, (2) membership to transnational networking organizations and (3) participation in transnational projects with other international partners. See: Stephen Barber, International, local and regional government alliances (Public Money \& Management, 1997).

Eurocities is a remarkable example on how urban transnational networks can enhance the competitiveness of specific local initiatives. See: http://www.eurocities.eu

Signed in 1992 by the European Community members. Upon ist entry into force in November 1993, it created the European Union and led to the creation of the single European currency, the euro. See: http://eur-lex.europa.eu/legal-content/EN/TXT/?uri=uriserv:xy0026.

Neil Brenner, Urban governance and the production of new state spaces in western Europe, 19602000 (Review of International Political Economy, 2004).

Renaud Payre, The Importance of Being Connected. City Networks and Urban Government: Lyon and Eurocities (1990-2005).

Alexander Murphy, Emerging regional linkages within the European Community: challenging the comination of the state (Tijdschrift voor Economische en Sociale Geografie, 1993).

Renaud Payre, The Importance of Being Connected. City Networks and Urban Government: Lyon and Eurocities (1990-2005).

Membership organisation in the United Kingdom that groups: 350 English councils, 22 Welsh councils, 31 fire authorities, 10 national parks and one town council. See: http://www.local.gov. uk/about.

Paul McAleavey and James Mitchell, Industrial regions and lobbying in the structural funds reform process (Journal of Common Market Studies, 1994). 2005). and Eurocities (1990-2005).

Association of five major emerging economies: Brazil, Russia, India, China and South Africa. Formally formed in 2009, they strive an alternative to Western institutions with an eye on development and cooperation on the basis of non-interference, equality, and mutual benefit. See: http://thebricspost.com. 
ASEAN - China Centre. "Regulations" (speech by Chinese President to Indonesian Parliament, Jakarta, October 2, 2013). Accessed October 17, 2015. http://www.asean-china-center.org/ english/2013-10/03/c_133062675.htm.

Barber, Stephen. "International, local and regional government alliances." Public Money \& Management (1997).

Bauman, Zygmunt. Globalization - The Human Consequences. New York: Columbia University Press, 1998.

Bloomberg. "China Cuts Interest Rates as Policy Divergence With U.S. Widens." Accessed October 24 , 2015. http://www.bloomberg.com/news/articles/2015-10-23/china-cuts-interest-ratesreserve-ratios-to-counter-slowdown.

Brenner, Neil. "Urban governance and the production of new state spaces in western Europe, 19602000.“ Review of International Political Economy (2004).

Brighton and Hove City Council. A European \& International Strategy for Brighton \& Hove City Council. 2007-2013. Accessed on October 17, 2015. https://www.brighton-hove.gov.uk/sites/ brighton-hove.gov.uk/files/European__International_Strategy.pdf

Commission of the European Communities, Green Paper on Territorial Cohesion - Turning Territorial Diversity into Strength. Brussels: Commission of the European Communities, 2008.

Constantinescu, Cristina, Aaditya Mattoo, and Michele Ruta. "The Global Trade Slowdown: Cyclical or Structural?". IMF Working Paper (2015).

European Commission, TEN-T Core Network Including Core Network Corridors. Brussels: Office for Publications of the European Communities, 2011.

European Commission, Trans-European Transport Network - TEN-T priority axes and projects. Luxembourg: Office for Publications of the European Communities, 2005.

Fallon, Theresa. "The New Silk Road: Xi Jinping's Grand Strategy for Euroasia“. American Foreign Policy Interests (2015).

Global Times. "China to help Romania high-speed rail." Accessed on October 1, 2015. http://www. globaltimes.cn/content/827633.shtml.

Global Times. "How Greece sees China's international role as client and partner."Accessed October 13, 2015. http://www.globaltimes.cn/content/762681.shtml.

Golonka, Marta. "Partners or Rivals? Chinese Investments in Central and Eastern Europe." Central \& Eastern European Development Institute (2012).

IMMUDTC (Informal Ministerial Meeting on Urban Development and Territorial Cohesion). Territorial Agenda of the European Union: Towards a more competitive and sustainable Europe of diverse regions. Agreed on the occasion of the Informal Ministerial Meeting on Urban Development and Territorial Cohesion. Accessed June 11, 2012. http://www.infocooperare.ro/ Files/Territorial\%20Agenda\%20of\%20the\%20European\%20Union_20093195.pdf.

IMMUDTC (Informal Ministerial Meeting on Urban Development and Territorial Cohesion). Territorial Agenda of the European Union: Towards an inclusive, smart and sustainable Europe of diverse regions. Agreed at the Informal Ministerial Meeting of Ministers responsible for Spatial Planning and Territorial Development. Accessed June 12, 2012. ntccp-udg.eu/system/ files/TA2020.pdf.

Institute of Medicine Committee on the Long-Run Macroeconomic Effects of the Aging U.S. Population. "Aging and the Macroeconomy". National Academy Press (2012).

International Monetary Fund. World Economic Outlook October 2015 - Adjusting to Lower Commodity Prices. Washington: International Monetary Fund, 2015.

ITE Oil \& Gas. "Black Sea offshore production in 2015 - a route to energy independence?."Accessed October 13, 2015. http://www.oilgas-events.com/market-insights/georgia-romania-russiaturkey/black-sea-offshore-production-in-2015-a-route-to-energy-independence-/801781383. 
KPMG. Mining in Africa Towards 2020. Accessed October 19, 2015. https://www.kpmg.com/ Africa/en/IssuesAndInsights/Articles-Publications/Documents/Mining\%20in\%20Africa\%20 towards\%202020.pdf.

McAleavey, Paul, and James Mitchell. "Industrial regions and lobbying in the structural funds reform process." Journal of Common Market Studies (1994).

Murphy, Alexander. "Emerging regional linkages within the European Community: challenging the comination of the state". Tijdschrift voor Economische en Sociale Geografie (1993).

OECD. What future for Health Spending? . Accessed on October 17, 2015. http://www.oecd.org/ eco/growth/aaaaaawhatfuture.pdf.

OPEC. Monthly Oil Market Report - 12 October 2015. Accessed October 18, 2015. http://www. opec.org/opec_web/static_files_project/media/downloads/publications/MOMROctober2015.pdf

Payre, Renaud. "The Importance of Being Connected. City Networks and Urban Government: Lyon and Eurocities (1990-2005).“ International Journal of Urban and Regional Research (2010).

Politics.HU. "Hungary, Serbia, China agree on upgrading Budapest-Belgrade railway." Accessed on October 22, 2015. http://www.politics.hu/20131126/hungary-serbia-china-agree-on-upgradingbudapest-belgrade-railway/.

Poulain, Loïc. “China's New Balkan Strategy”, Central Europe Watch 2 (2011).

Richard Rose. Learning from Comparative Public Policy: A Practical Guide (Abingdon: Routledge, 2005).

Stefanie Dühr, Claire Colomb, and Vincent Nadin. European Spatial Planning and Territorial Cooperation (Abingdon, Oxon: Routledge, 2010).

The Economist. "Getting the machines revving." Accessed October 2, 2015. http://www.economist. com/blogs/freeexchange/2015/03/quantitative-easing-and-euro.

The Economist. "The Fed's plan to hike interest rates." Accessed September 26, 2015 http://www. economist.com/blogs/economist-explains/2015/08/economist-explains-21.

The Guardian. "Chinese carrier Cosco is transforming Piraeus - and has eyes on Thessaloniki." Accessed March 20, 2015. http://www.theguardian.com/world/2014/jun/19/china-piraeusgreece-cosco-thessaloniki-railways.

The UN Refugee Agency. "Refugee sea arrivals in Greece this year approach 400,000." Accessed October 13, 2015. http://www.unhcr.org/560e63626.html.

Trans Adriatic Pipeline. Accessed on October 25, 2015. http://www.tap-ag.com/assets/08.about us/english/TAP_Corporate_Brochure_June\%202015_EN_Updated.pdf.

UNCTAD (United Nations Conference on Trade and Development). Review of Maritime Transport 2015. Geneva: United Nations Publication, 2015.

United Nations. World Population Prospects - Key findings \& advance tables - 2015 Revision. New York: United Nations Publication, 2015.

World Bank Group. Global Economic Prospects June 2015 - The Global Economy in Transition. Washington: The World Bank, 2015.

World Trade Organization. World Trade Report 2014 - Trade and development: recent trends and the role of the WTO. Geneva: World Trade Organization, 2014.

Yercan, Funda, and Turkay Yildiz. "International maritime trade and logistics." In Maritime Logistics, eds. Dong-Wook Song and Photis M. Panayides. London: Kogan Page, 2012.

http://thebricspost.com

http://www.eurocities.eu

http://eur-lex.europa.eu/legal-content/EN/TXT/?uri=uriserv:xy0026.

http://ec.europa.eu/transport/infrastructure/tentec/tentec-portal/site/en/abouttent.htm.

https://www.ecb.europa.eu/stats/exchange/eurofxref/html/eurofxref-graph-usd.en.html.

http://knoema.de 


\section{STRATEGIJA INTEGRALNOG URBANOG RAZVOJA KAO INSTRUMENT UPRAVLJANJA URBANIM RAZVOJEM \\ Ratka Čolić}

U radu je fokus na izazove institucionalizacije novog instrumenta planiranja - Strategije integralnog urbanog razvoja (SIUR). Započinje sa diskusijom o podsticanju novina u upravljanju urbanim razvojem, uticaju evropskih politika urbanog razvoja i primeni novog planskog instrumenta. Podsticano zahtevima za efektivnijim i fleksibilnijim planiranjem, upravljanje urbanim razvojem je uticalo na primenu različitih instrumenata u praksi. Jedan od njih je i strategija integralnog urbanog razvoja. Procesi izrade strategija u tri srpska grada predstavljaju prva iskustva operacionalizacije kolaborativnog pristupa i integralnog strateškog planiranja urbanog razvoja u Srbiji kao postsocijalističkom kontekstu, koji se prilagodjava tržišno orijentisanom modelu planiranja. Kao takav, poseduje endogeni karakter i značenje u okviru lokalne prakse planiranja. Kao ključni izazovi primene strategije izdvojeni su razumevanje očekivanih ishoda njene primene i postojanje potencijala za promene. U domenu pokazatelja institucionalizacije novog instrumenta lokalni urbanisti su ukazali na značaj obezbeđivanja dalje tehničke podrške, prve iskorake u implementaciji strategija, dalje razvijanje kapaciteta i uvođenje bolje komunikacije i uspostavljanje relacija. Kao novi upravljački i planski instrument strategija je postala predmet analize u sferi uprave, struke i akademske zajednice.

KLJUČNE REČI: UPRAVLJANJE URBANIM RAZVOJEM, STRATEGIJA INTEGRALNOG URBANOG RAZVOJA, PRVA ISKUSTVA U PRIMENI KOLABORATIVNOG PLANIRANJA URBANOG RAZVOJA, IZAZOVI IMPLEMENTACIJE

\section{PROSTORNI I SAOBRAĆAJNI RAZVOJ DUŽ EVROPSKIH KORIDORA: JAČANJE KAPACITETA LOKALNIH AKTERA \\ U TRANSNACIONALNOJ SARADNJI}

\section{Pablo Accebillo}

Integrisani prostorni i saobraćajni razvoj koridora je jedna od strategija kojom se utiče na trgovinu, ekonomski i demografski učinak u linearnim sistemima širom sveta. Međutim, takav razvoj se može razraditi na različitim nivoima: od istraživanja dinamike transnacionalne saradnje, preko analiziranja stepena integracije između prostornih i saobraćajnih politika u državama duž koridora, do fokusiranja na ulogu lokalnih aktera u nadnacionalnim pitanjima. Pošto ovaj rad predstavlja prvu fazu evropskog projekta transnacionalne saradnje u oblasti integrisanog prostornog i saobraćajnog razvoja duž Hamburg-Atina koridora u okviru programa infrastrukture iniciranog od strane Evropske Komisije, rad ima za cilj da pruži naučno zasnovan pregled najznačajnijih aspekata pomenutog koridora. Karakter rada je uglavnom opisni i shodno tome rasvetljava istraživanja u toku koja se sprovode kroz pomenuti projekat. U tu svrhu se koristi multi-skalarna perspektiva (tj. globalna, regionalna, lokalna) za analizu pojedinih indikatora vezanih za trgovinu, privredu i demografiju. Veruje se da takav temeljan prikaz obezbeđuje bolji pregled trenutne situacije. U završnom delu rada ukratko su date opšte preporuke za jačanje uloge lokalnih vlasti u složenom procesu transnacionalne saradnje.

KLJUČNE REČI: TRANSNACIONALNOST, TRGOVINA, EKONOMIJA, DEMOGRAFIJA, TRANSPORT, PROSTORNI

RAZVOJ, SARADNJA HAMBURG-ATINA KORIDOR

\section{RAZVOJ ŽELEZNICE I URBANI RAZVOJ U PATRASU: \\ KA UNAPREĐENJU UČEŠĆA LOKALNE SAMOUPRAVE U KOMPLEKSNIM PROBLEMIMA PLANIRANJA}

\section{Theodora Papamichail}

U poslednjih nekoliko godina, tema integrisane infrastrukture i urbanog razvoja, pored formalnih politika planiranja, promoviše pristup odozdo-na-gore. Ovo se posebno odnosi na kompleksne institucionalne okvire koje je potrebno osnažiti učešćem zainteresovane javnosti. Zbog društveno- 